\title{
The Effect of Job Analysis on Service Delivery in Federal Airports Authority of Nigeria (FAAN) 2005-2014
}

\author{
Igbokwe-Ibeto, C.J PhD \\ School of Public Management, Governance and Public Policy \\ University of Johannesburg, Auckland Park 2006, South Africa
}

Received: March 5, 2019 Accepted: March 26, 2019 Online published: May 5, 2019

doi:10.5296/ijhrs.v9i2.14745 URL: https://doi.org/10.5296/ijhrs.v9i2.14745

\begin{abstract}
The issue of public service delivery has been a high priority subject for organizational researchers and practitioners alike in Nigeria. However, linking human resource management practices such as job analysis that has received considerable attention in developed western countries as a useful human resource planning tool towards improving service delivery in the country is relatively new and requires scholarly attention particularly in the context of Nigerian public sector organizations. Within the framework of New Public Management (NPM) theory, the study examined the effect of job analysis on service delivery in the Federal Airports Authority of Nigeria (FAAN) 2005-2014. The study was guided by two research questions and hypotheses. The study adopted the survey research design. The study relied on primary and secondary data, and multiple stage sampling technique was used to select the sample population. Pearson Product Moment Correlation Coefficient and Simple Regression Analyses statistical techniques were used with the aid of Statistical Package for the Social Sciences (SPSS) to test the research hypotheses. Findings of the study show that job analysis has a significant effect on employee commitment in Federal Airports Authority of Nigeria at the 5percent levels. There is also a significant relationship between job analysis and quality of service delivery at the conventional 5percent levels. Given the pivotal role that job analysis plays in the $21^{\text {st }}$ century, FAAN should adopt the conduct of job analysis as a basic human resource management tool for proper personnel utilization and improve quality of service delivery. FAAN should through job analysis, identify and develop proper employee commitment scheme, such as training and retraining, and performance review standards that could enhance service delivery. It should also make expertise available to conduct job analysis. This would assist to ensure that all critical aspects such as skills, knowledge and competencies are taken into consideration thereby eliminate the concept of garbage in
\end{abstract}


garbage out.

Keywords: efficiency, effectiveness, description, interface, performance, specification

\section{Introduction}

The issue of public service delivery has been a high priority subject for organizational researchers and practitioners alike. Models of service delivery have acknowledged that it is affected by job analysis (Dibie, 2014; Cavanaugh, 2011). Strategic human resources planning determines the number of people and skills needed. However human resources planning does not specify how each job is performed (Dibie, 2014). According to Dibie, Edoho \& Dibie (2015), job analysis assists in establishing what the position entails and the qualifications required of the job holder. Several scholars contend that job analysis is the basis of job description and job specifications (Lussier \& Achua, 2017; Griffin, Phillips \& Gully, 2017). Job description identifies the tasks and responsibilities of the position while job specification identifies the qualifications needed by the person who is to fill a position, (Hitt, Ireland, \& Hoskisson, 2017; Lussier, 2012). Dibie et al. (2015) argued that part of the job of job analysis should be to develop a realistic job preview. The realistic job preview provides the candidate with an accurate, objective understanding of the job.

In the Western developed countries, job analysis as a basic Human Capital Management (HCM) practice has gone through a paradigm shift from a micro-analytical approach to macro-strategic approach (Hitt et al., 2017; Griffin et al., 2017; Rehman et al., 2010). Employees who are of the view that they were given proper job descriptions appear more contented with the organization. Such employees also believe that the employer stands behind them and is trustworthy. Employees that have benefited from accurate job descriptions often would express a lesser desire to switch over jobs than those who feel that they were not given accurate guidelines on how to carry out their duties for the organization (Dibie, 2014).

However, in a developing economy such as Nigeria, job analysis as a basic HRM tool has not bee fully explored and analyzed especially in the public sector context. This is a serious problem of capacity building in the country because of the following reasons: First, the best qualified candidates are not often hired for positions. Second, the nation's quota system policy encourages people from ethnic groups with very low academic and professional qualification to be hired while highly qualified candidates from affluent ethnic groups are left unemployed. Thus, the function of HCM in Nigeria does not necessarily entail the process of attracting the best qualified candidates to apply for job vacancies like in western developed countries (Dibie et al., 2015).

The bone of contention is why does job analysis deserve a scholarly investigation instead of the popularly known capacity building and human resources problems in the Nigerian public sector? This is because creation of job positions without corresponding tasks and functions will render incumbents of such position redundant and useless (Briggs, 2007; Ukaegbu, 1995). Corroborating the above submission, Chukwuemeka (2013) argues that most public sector employees' in Nigeria do not know what they are expected to do. Some do not even know the target of their department and as such do not know where to start, end or go. It would appear 
job analysis where task or responsibility is clearly defined is at the root of the matter because it is only when individuals put their mental and physical energies to use, that tangible or intangible results can be achieved. However, in developing economies like Nigeria, the influence of government in State-Owned Enterprises' (SOEs) renders many human resource management best practices ineffectual. Many HRM practices have been trailed by awkward personal influences and as such it should be noted that a virtuous and holistic HRM would eliminate the concept of "garbage in garbage out" (Obisi, 2003). This study therefore seeks to examine the effect of job analysis on service delivery in the Nigerian public sector organizations.

\section{Statement of the Problem}

The job of the human resources department is to provide the right kinds of people, in the right quantity, with the right skills, at the right time but this is not often the case in Nigeria and most African countries (Dibie et al., 2015). While human resources management in the public sector in Nigeria should be based on the mission, goals, and strategy of the federal government, ineffective HRM practices have not galvanized higher levels of performance and sustained competitive advantages in some ministries and public agencies in the county (Griffin et al., 2017; Dibie, 2014).

In order to ensure that the Nigerian public sector agencies are efficient in achieving government's policy objectives, it has become imperative to investigate the nature of job analysis in the country. This is particularly important since in the Nigerian public service, the issue of poor service delivery, low work content, and conflict of duties, compensation problem and irrational job titles which bore little or no resemblance to the actual work performed by an employee abound. In addition, cases of misuse of labour where employees are not being assigned work in accordance with their grades, wages and educational level differentials that has hindered public service delivery in the country have been reported (Mapira et al., 2013). It is a common phenomenon in Nigeria to enter a section of government department and see that out of about 10 employees in an office; only 3 or 4 are consistently busy. The rest are either idle or perform skeletal tasks at intervals, a phenomenon which Chukwuemeka (2013); Briggs (2007) and Mukoro (2005) argue could be attributed to inadequate and invalid standard for evaluating jobs due to the absence of job analysis.

In the western countries, job analysis is used as a basic HRM tool to enhance service delivery (Hitt et al., 2017; Dibie, 2014; Cascio, 2010; Rehman et al., 2010). It is the process of recording information about a job and determining the duties and skills requirements of the job as well as compensations of job holders which promote service delivery (Dibie, 2014; Klingner, Nalbandian, \& Llorens, 2010). However, Chukwuemeka (2013) contends that in Nigeria, most public sector employees do not know what they are expected to do and as such do not know where to start or end because of the absence of job analysis where tasks and responsibilities are clearly defined.

These seemingly abnormal work behaviors have prompted a number of studies aimed at ameliorating the ugly situation. For example, Newman (2011) examined effects of job analysis on personnel utilization in Nigerian Ports Authority of Nigeria (NPA), while Briggs 
(2007) examined the use of job description and job specification in the Nigerian federal civil service. It appears that in spite of efforts to improve service delivery in Nigerian public sector, not much has changed in terms of the public goods and services expected of it. Their performance still remains below public expectations. All these challenges prompted the researcher to seek to examine the effect of job analysis on service delivery with specific reference to Federal Airports Authority of Nigeria (FAAN).

\section{Research Questions}

To interrogate the effect of job analysis on service delivery in Federal Airports Authority of Nigeria (FAAN) 2005-2014 in this study, efforts will be made to beam our search light on the following research questions which will serve as a guide to the survey in the quest for answers to the problem being investigated.

1. Is there any relationship between job analysis and quality of service delivery in the Federal Airports Authority of Nigeria?

2. Does job analysis have any significant effect on employee commitment in the Federal Airports Authority of Nigeria?

\section{Conceptual and Theoretical Underpinning}

In social and management sciences research, in order to avoid ambiguity in the interpretation and understanding of certain concepts, it is customary to begin an academic investigation by examining the conceptual and theoretical contours of the subject matter of analysis by analyzing the views of various scholars and authors as well as the way in which one's research is integrated into the body of existing theories and research because conceptual and theoretical analyses provide a road map for navigating the contour of social phenomena (Igbokwe-Ibeto, Anazodo \& Osakede, 2015). Though, consensus may not be achieved on the validity or otherwise of such enterprise. Nonetheless, it is an exercise worth pursuing if only to sketch the parameters of the subject matter (Igbokwe-Ibeto et al., 2015). This is the intent of Babbie \& Mouton (2001) methodological research diction that "we specify why we use particular terms for the purpose of facilitating their contextual definition and comprehension." In this section of the paper, we shall attempt to effectuate this endeavor. The key variables of the research to be conceptualized are job analysis and service delivery.

Scholars and human resource practitioners have different definition of job analysis. Job analysis is the process of recording information about the work performance of an employee (Dibie et al., 2015). According to the U.S. Office of Personnel Management (2008), a job analysis is a systematic procedure for gathering, documenting, and analyzing information about the content, context, and requirements of the job. It demonstrates that there is a clear relationship between the tasks performed on the job and the competencies, or knowledge, skills, and abilities (KSAs) required in performing the tasks of public service delivery.

Public as used here is an adjective qualifying service, 'public service'. It distinguishes the public service which is the main concern of this study from that which is strictly private. In other words, which public or what constitutes the public that provide public service? Here, 
the focus is on the organized public sector of the economy i.e. services provided by Ministries, Departments and Agencies (MDAs) in contrast to the private sector, who in position of authority from position of legitimacy act in their position in accordance with the laid down rules and regulations e.g. public servants, legislators, President.

As a concept, "public service" is not easily defined. However, to avoid any ambiguity or misinterpretation, Section 318 of the 1999 Constitution as amended, defines the public service of the Federation as:

Service of the federation in civil capacity as staff of the office of the President, the Vice President, Ministry or Department of the Government of the Federation assigned with the responsibility for any business of the Government of the Federation (FRN, 1999).

Public service delivery simply put is getting public goods and services as expected and as quickly as possible by (recipients) citizens (Fagbemi, 2006). In the view of O'Toole Jr. \& Meier (2011), service delivery refers to the achievement of public programmes and organizations in terms of output and outcomes that they produce. According to Oronsaye in (Onyekwelu, 2016), service delivery is the process of getting the needs of citizens through prompt and efficient procedures. It presupposes that the interaction between citizens and government results in value creation. According to Akhakpe (2014), public service delivery is the provision of goods and other life support amenities by government to maximize the welfare and well-being of the people. The above definitions of public service delivery are all encompassing and a close examination of the definitions suggests that public service delivery is the degree and hallmark of excellence in the public service.

As is the tradition in social and management sciences, no one theoretical approach can adequately explain a social phenomenon. Nonetheless, we need a platform on which to interrogate our subject of discourse because theoretical analysis is embarked upon to clarify, illustrate and provide a road map for navigating the contour of social phenomena. For this purpose and bearing in mind the constraints before us, we find the New Public Management (NPM) theory, a term formally conceptualized by Hood (1991) which according to Lueder (1996), Reichard (1996), and Dunsire (1995) has its origins in public choice theory and managerialism useful to anchor the study. This is because when issue of public service delivery is raised in the contemporary times, the NPM theory comes out forcefully.

As a new paradigm in public administration, New Public Management points to the failures and inadequacies of public service delivery over time and the problems lying squarely in the nature and processes of public sector activity and traditional public administration theories. NPM has been developed as a handy shorthand and summary description of the way of reorganizing public sector agencies to bring their management approaches closer to business methods (Dibie, 2014).

The summary of the various views taken together, isolate the NPM theory as relevant in analyzing the subject matter of job analysis and service delivery because whenever the issue of public sector efficiency and effectiveness is mentioned in contemporary times, the NPM 


\section{Macrothink}

International Journal of Human Resource Studies

ISSN 2162-3058

2019, Vol. 9, No. 2

theory comes out forcefully. Thus, the examination of job analysis and service delivery based on this theory enables us to have the bases for accessing Federal Airports Authority of Nigerian (FAAN) as regards job analysis practices and its effect on service delivery.

However, all theories are born refuted, the NPM theory not an exception. The exponents of the theory fail to recognize that the ecology of public administration varies from one country to another and that the culture of any given society can hinder or accelerate its growth and development. For instance, while the Western bureaucratic theories demand that public administrators should be impersonal, discipline, achievement oriented and individualistic, African cultural values promote and encourage vibrant interpersonal, informal relationship build around group or communal interest. Therefore, leading to clash between public administrators and cultural values which invariably result into epileptic service delivery.

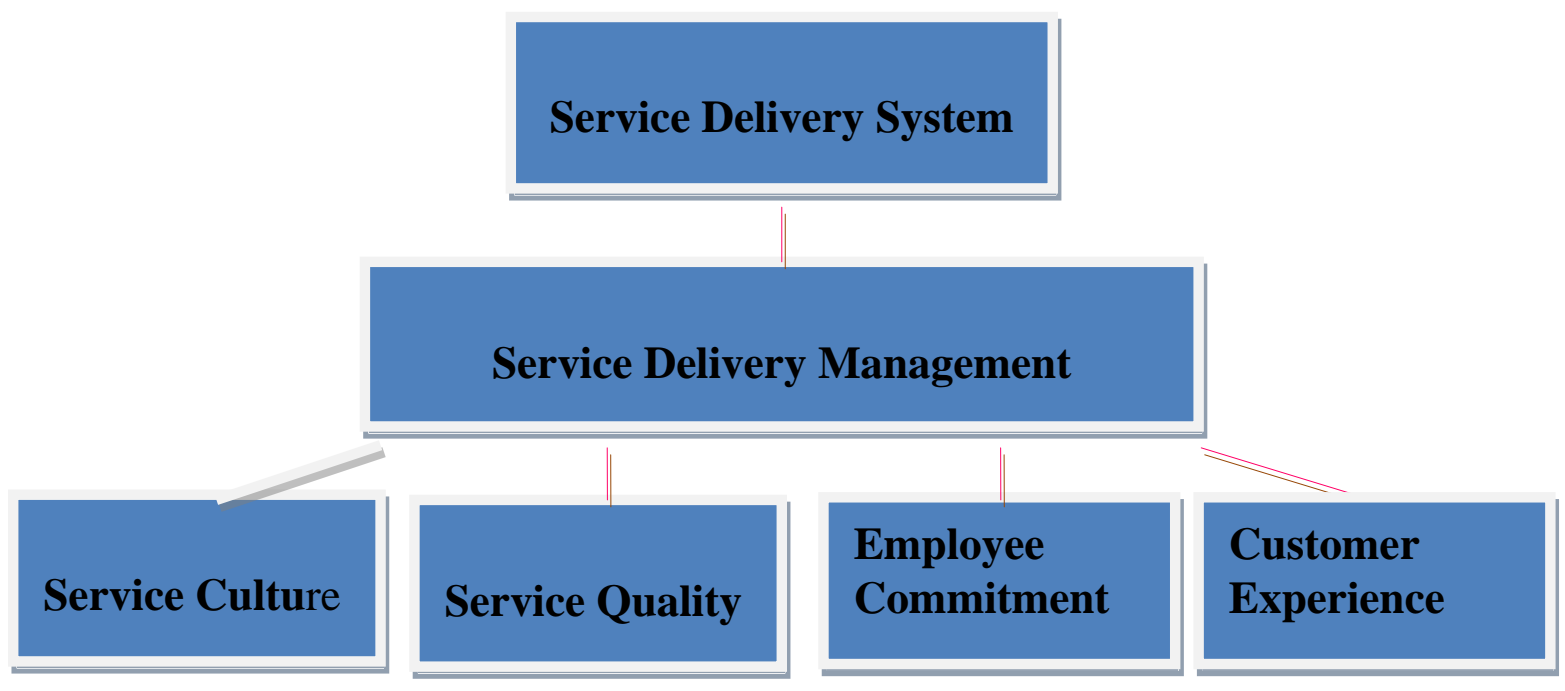

Figure 1. Key Elements/Components of Service Delivery

Source: Adapted from ISS (2015)

According to ISS (2015), there are four main elements for effective and efficient service delivery which include service culture, quality of service, employee engagement and customer experience. However, for our purpose in this study, we shall operationalize two components of service delivery namely service quality and employee commitment as well as be examining the nexus between the variables in line with the research questions. According to Kofler, Armstrong, Saunders \& Wing in (Onyekwelu, 2016), quality of service refers to the totality of features and characteristics of a product or services that bear on its ability to satisfy stated or implied needs. Agbor in (Onyekwelu, 2016) conceived service quality as the extent to which customers' perception of service meet and or exceed their expectations.

\section{The Nexus between Job Analysis and Service Delivery}

Indeed, in the current public management discourse, the term public service delivery is associated with questions of the efficient and effective administration of government policies. This view draws from the social contract theory particularly that of Jean Jacque Roussesau 
who argues that the essences of government anywhere is to fulfill the general will of common good through the provision of social services such as security, education, housing, roads and any other amenities that could uplift the material condition of the people. Olowu (2011) corroborated the foregoing statement when he argues that public service delivery is a top priority in developing countries, if they are to make any meaningful progress in socio-economic development. The provision and quality of essential services are key ingredients of measuring good governance as public service delivery underpin the social contract between the state and her citizens.

It is worthy of note that human existence depends on basic necessities of life, such as water, food, shelter and sanitation. In fact, the Marxist school of thought argues that human beings will cease to exist in the absence of these amenities (Sexton, 2008). Therefore, the primary responsibility of any public administration system is to deliver essential services to the citizens most especially services that the private sector may not be in position to provide. Also, the services should be provided at affordable prices. Indeed, the ability of a government to govern and tax people is premised on its capacity and capability to deliver public goods and services required by its population. This indicates that government derives its existence and legitimacy from the services it renders which the possibility of market failure is high (Olowu, 2011). Therefore, creating an enabling environment for the citizens and non-citizens alike to meet their basic needs is one of the main pillars of good governance.

The consumer of public goods and services could be regarded customer or client. To Fagbemi (2006), "a customer or a client is the direct recipient of a service through dealing with the service providers". For our purpose in this study, the customers of public services are the citizens while the provider is the government at all levels. According to Nash \& Nash in (Akhakpe, 2014), customer service delivery is therefore, the provision of services to a client (buyer) in such a manner that the client's expectations are realized or surpassed while at the same time, the government agency remains stable. The success of any public organization to a large extend depends on HR methods and strategies adopted. Service delivery is not only a result of well-functioning system but also depends on effective human resource management practice such as job analysis that succeeds in attracting, developing, and maintaining a committed and motivated workforce (Al-Ahmadi, 2009).

\section{Interface between Job Analysis and Service Quality}

Sheu (2005) see employee commitment as "translating employee potential into employee performance and organizational success and thus changing the way employees perform by utilizing the tools in the armory of internal communication professionals". It has been observed that the assumption underpinning the practice of human resources management (HRM) practice is that people are the organization's key resource and service delivery largely depends on them (Armstrong, 2010). Therefore, if an appropriate range of HR policies and processes are developed and implemented effectively, HR will make a substantial impact on public service delivery (Igbokwe-Ibeto, Akhakpe \& Agboola, 2013; Apospori, Nikandrou, Brewster \& Papalexandris, 2008). 


\section{Mll Macrothink}

International Journal of Human Resource Studies

ISSN 2162-3058

2019, Vol. 9, No. 2

Corroborating the above views, Dessler, Cole \& Sutherland (2012); Bohlander et al. (2009); Schuler \& Jacksoon (1996) examine the importance of conducting job analysis and acknowledged job analysis in relation with work behaviors and associated tasks required for successful service delivery. Job analysis provides a foundation of requisite information regarding jobs and employees that HR professionals used to build up important documents such as job description, job specifications and performance appraisal (Harvey, 1991).

Bohlander et al. (2009) argues that the definitive rationale of job analysis is to improve output of an employee or organization. No wonder Dibie (2014) and Clifford (1994) admonish that organizations admiring the importance of job analysis and regularly practicing conduct of job analysis have a better knowledge and understanding of their employees' and organizational strengths and weaknesses, accordingly a timely remedial action may be taken to improve their deficiency in culture, skills and abilities.

Conducting regular job analysis can assist an organization in establishing an appropriate infrastructure by determining the tasks to be performed as well as the deadlines for performing them thereby creating a framework for service delivery appraisal (Dibie, 2014). Regular practice of job analysis contributes to the public service delivery by enhancing a positive job attitude and dedication. In addition, job analysis is capable of identifying factors such as employees' motivation and job satisfaction. A normal review of job descriptions and service delivery standards by applying job analysis enormously help HR professionals and researchers to recognize and eradicate redundant job requirements and areas of divergence causing job frustration (Monday, Noe \&Premeaux, ,2002; Gomez-Mejia, Balkin\&Cardy, 2010).

\section{Methodology}

According to Lerche in (Asika, 2006), after our research problem is clarified, our variables selected and hypotheses listed; what we need is research design. To investigate the effect of job analysis on service delivery in the Federal Airports Authority of Nigerian, this research employed the descriptive survey method, with the researcher setting out to illustrate the association that exists between the dependent and independent variables. The researcher's main goal in a descriptive study is to describe accurately the relationship between two or more phenomena (Mouton \& Marais, 1990).

The population of this study consists of the officials from eight directorates in Federal Airports Authority of Nigeria (FAAN) since the conduct of job analysis and service delivery is a cross-departmental collective responsibility. The actual population of FAAN's staff as at the time of this study is 10,994 (Field Survey, 2015). Given the population of 10,994 civil servants from FAAN chosen for this study, the sample size of the study 386 was determined using Taro Yamani's (1967) statistical formula for sample size determination. Thus, Yamani (1967) statistical formula is given as: 


$$
\mathrm{n}=\frac{\mathrm{N}}{1+\mathrm{N}(\mathrm{e})^{2}}
$$

Where $\mathrm{n}=$ sample size

$\mathrm{N}=$ Population of the study

$\mathrm{e}=$ Sampling error (in this case 5percent)

Having determined the sample size, the researcher proceeded by sharing the obtained data among the various directorates in FAAN using Rangan Kamaisan proportional allocation or distribution method. This was to ensure that none of the directorate in the organization under survey is cheated. The formula is given thus:

$$
\begin{aligned}
& \mathrm{ns}=\mathrm{Np} \times \mathrm{n} \\
& \mathrm{ns}=\quad \text { Sample size allocated to each unit } \\
& \mathrm{Np}=\text { Population size of each unit } \\
& \mathrm{n} \quad=\text { Total sample size } \\
& \mathrm{N} \quad=\text { Total population size }
\end{aligned}
$$

Having determined the sample allocation size of each directorate, the researcher proceeded to determine the staffs that will participate in the study among the various directorates in Federal Airports Authority of Nigeria. Based on this, $\mathbf{N}$ small cards with numbers 1-120 and $1-50$ as the case may be, depending on directorate's staff strength were prepared for sampling and put in a box. Then, the $\mathbf{n}$ cards were randomly picked by each directorate staff. Those (staff) that picked $\mathbf{1}$ to the actual number required for each directorate automatically became part of the sample.

Consequently, in order to test the research hypotheses and establish the relationship and the strength of the relationship between the variables under investigation, Pearson Product Moment Correlation Coefficient (PPMC) and Simple Regression Analysis techniques were used as quantitative statistical tools for this study. While Pearson Product Moment Correlation Coefficient is used as a tool for establishing the relationship between two or more variables, Regression Analysis determines the extent to which dependent variable is explained by independent variables. Pearson Product Moment Correlation Coefficient (PPMC) was used to test hypothesis I while hypothesis II on the other hand was addressed through the application of Simple Regression Analysis.

\section{Preliminary Data Analysis}

The researcher distributed a total of three hundred and eighty -six (386) questionnaires of thirty-seven (37) items each to members of staff of the Federal Airports Authority of Nigeria (FAAN). As a result of frequent persuasion on the importance of responding fully and honestly to the questionnaire, the researcher was able to achieve questionnaire return of three 
hundred and fifty-six (356) responses while thirty (30) were not returned out of the total distributed three hundred and eighty -six (386). Out of these numbers, twenty-two (22) copies of the questionnaire were not properly filled, leaving a total of three hundred and thirty-four (334) usable questionnaires yielding a response rate of 87percent. The researcher proceeded with the analysis of the data as 87 percent response rate is regarded as very satisfactory for this study. According to Babbie and Mouton (2001), some rules of thumb about the return/response rate is that a response rate of 50percent is adequate for analysis and reporting, 60 percent is good while 70percent is very good.

\section{Presentation and Analysis of Data According to Test of Hypotheses}

To determine the effect of job analysis on service delivery in Federal Airports Authority of Nigeria (FAAN) 2005-2014, the following two research hypotheses will be tested for the purpose of this research using Pearson Product Moment Correlation Coefficient (PPMC) and Regression Analysis techniques.

\section{Hypothesis I}

$\boldsymbol{H}_{0}$ : There is no significant relationship between job analysis and quality of service delivery in the Federal Airports Authority of Nigeria.

$\boldsymbol{H}_{1}$ : There is a significant relationship between job analysis and quality of service delivery in the Federal Airports Authority of Nigeria.

Table 1. Correlations Estimate

\begin{tabular}{l|l|l|l}
\hline \multicolumn{2}{c|}{} & Job Analysis & Service Delivery \\
\hline \multirow{3}{*}{ Job Analysis } & $\begin{array}{l}\text { Pearson } \\
\text { Correlation }\end{array}$ & 1 & .824 \\
\cline { 2 - 4 } & Sig. (2-tailed) & & .003 \\
\cline { 2 - 4 } & $\mathrm{N}$ & 334 & 334 \\
\hline \multirow{2}{*}{$\begin{array}{l}\text { Quality of } \\
\text { Service } \\
\text { Delivery }\end{array}$} & $\begin{array}{l}\text { Pearson } \\
\text { Correlation }\end{array}$ & .824 & 1 \\
\cline { 2 - 4 } & Sig. (2-tailed) & .003 & 334 \\
\cline { 2 - 4 } & $\mathrm{N}$ & 334 & \\
\hline
\end{tabular}

Correlation is significant at the 0.05 level (2-tailed

The symmetric matrix with Pearson correlations given above shows that the Pearson Product Moment correlation coefficient is 0.824 , it demonstrates that job analysis has a very high positive correlation with quality of services. The relationship is statistically significant because the p-value of the result (0.003) is less than the level of significant used for the study $(0.05)$.

Decision: From the computation above, the p-value of the result (0.003) is less than the level of significant used for the study (0.05). Thus, the level of significant used for the study (0.05) is greater than the p-value of the result (0.003). On the basis of this, we can therefore reject the null hypothesis and accept the alternative hypothesis and conclude that there is a 
significant relationship between job analysis and quality of service delivery in the Federal Airports Authority of Nigeria. In a similar study, Ajayi (2012) did a study on the effect of records management on public service delivery in Federal Airports Authority of Nigeria and discovers a significant relationship between records management and public service delivery.

Implication: The implication of the result of hypothesis one which states that there is a significant relationship between job analysis and quality of service delivery in the Federal Airports Authority of Nigeria is that, lack of proper conduct of job analysis by public sector organizations' create room for lack of fit between job and job holders in the public service thereby making the system unproductive and at the same time inhibiting service quality and national development. Empirical evidence appears to support the view that HRM practices like job analysis can influence the quality of services and organizational growth. Organizations interested in the growth and high quality of services should involve their employees in decision making process for creating high level of employees' job satisfaction and enhancing their productivity, reducing turnover and increasing job security. Those organizations, which make effective use of HRM practices on a wider scale, can generate higher returns. Sometimes, it happens when managements don't know something what employees know. Therefore, the immediate priority for policy makers and public sector managers in Nigeria is to re-examine the reliability and validity of traditional public administration theories still in use with the aim of adopting the New Public Management model that emphasis goals and targets should be defined and measurable as indicators of quality of services and service delivery. The main thrust of the new public management theory is not with what to do but how to do it better.

\section{Hypothesis II}

$\boldsymbol{H}_{\text {0: }}$ Job analysis has no significant effect on employee commitment in the Federal Airports Authority of Nigeria.

$\boldsymbol{H}_{1:}$ Job analysis has a significant effect on employee commitment in the Federal Airports Authority of Nigeria.

Table 2. Regression Estimates Coefficients

\begin{tabular}{|c|c|c|c|c|c|}
\hline \multirow[b]{2}{*}{ Model } & \multicolumn{2}{|c|}{$\begin{array}{c}\text { Unstandardized } \\
\text { Coefficients }\end{array}$} & \multirow{2}{*}{\begin{tabular}{|l|}
$\begin{array}{c}\text { Standardized } \\
\text { Coefficients }\end{array}$ \\
Beta \\
\end{tabular}} & \multirow[b]{2}{*}{$\mathrm{T}$} & \multirow[b]{2}{*}{ Sig. } \\
\hline & $\mathrm{B}$ & Std. Error & & & \\
\hline 1 (Constant) & -0.127 & .052 & & -2.444 & .016 \\
\hline Job analysis & 1.018 & .022 & .970 & 45.654 & .000 \\
\hline $\mathrm{R}$ & $=$ & .971 & & & \\
\hline $\mathrm{R}^{2}$ & $=$ & .942 & & & \\
\hline Adj $R^{2}$ & $=$ & .941 & & & \\
\hline F ratio & $=$ & 15.01 (Sig. & @ 0.001) & & \\
\hline
\end{tabular}

a. Dependent Variable: Employee Commitment 
The coefficient of determination (0.942) in the model summary above shows that $94.2 \%$ of the variations recorded in employee commitment in the Federal Airports Authority of Nigeria is accounted for by the variations recorded in job analysis. Also, the calculated $\mathrm{F}$ ratio value of 15.01 and t-statistic of 45.654 for the job analysis variable are both significant at the conventional 0.05 level of significance. These then imply that job analysis has significant effect on employee commitment in the Federal Airports Authority of Nigeria.

Decision: From the computation above, the p-value of the coefficient of job analysis $(0.000)$ and that of the $\mathrm{F}$ ratio are both less than the level of significant used for the study (0.05). On the basis of these, we reject the null hypothesis and accept the alternative hypothesis and conclude that job analysis has a significant effect on employee commitment in the Federal Airports Authority of Nigeria. In similar vein, Alegbeleye (2014) did a study on the Impact of Monetization on Employees performance in the Federal Airports Authority of Nigeria and discover a significant between monetization and employee's performance; Igbokwe-Ibeto \& Aremo (2013) did a study on reward and reward management: an antidote for productivity enhancement in the Nigerian public sector organizations and confirm a significant relationship between reward and employee's productivity.

Implication: The implication of the result of hypothesis two which states that job analysis has a significant effect on employee commitment in the Federal Airports is that so long the Nigerian public sector organizations continue to down play the conduct of job analysis, cases of misuse of labour where employees' are not assigned work in accordance with their grades, wages and educational level differentials will remain unresolved and thereby hindering service delivery. The research provides proofs for FAAN in particular and public sector agencies in general that whenever the employee and cooperate objectives are not properly integrated, employees are not satisfied with their job, thus, service deliver is always low and could lead to labour turnover.

\section{Conclusion}

The main aim of the study is to examine the effect of job analysis on service delivery, with specific reference to Federal Airports Authority of Nigeria (FAAN). The research was guided by two research objectives and hypotheses. From the research findings, this study reveals a diverse aspect of a practical operation of job analysis in human resource management. It argues that well established job analysis has positive implications on service delivery in Federal Airports Authority of Nigeria. However, the study observed that job analysis as an important aspect of human resource management was being ignored in public sector jobs. Job analysis paves way for unassailable human resource management process, instead of using traditional methods; the public sector agencies has to consider the possibility of employing job analysis as the primary HRM tool with its positive implications on public service delivery.

In review of relevant empirical literature and the subsequent testing of the two stated hypotheses, we came to the conclusion that job analysis has a significant relationship between job analysis and quality of services in the Federal Airports Authority of Nigeria. Secondly, that job analysis has a significant effect on employee commitment in the Federal Airports 
Authority of Nigeria.

\section{Recommendations}

In view of the findings of this study, it is obvious and imperative that for government to resolve the issues of conflict of duties, inadequate compensation and irrational job titles, misuse of labour which has hindered public service delivery in the country, the conduct of job analysis should be taken serious by public sector managers. Based on the findings, we recommend that:

1. Federal Airports Authority of Nigeria in particular and public sector organizations in general should avail themselves the windows of opportunities that job analysis provides in their drive to enhance quality of service delivery. They should adopt the conduct of job analysis as a basic human resource management tool for proper personnel utilization and improved quality of service delivery. The study provides a proof that through proper conduct of job analysis, public sector organizations can ascertain the fit between job and job holders because whenever an employee is not properly matched with his or her job, quality service delivery can hardly be guaranteed. This could lead to high rate of labor turnover, and when an employee quit the organization, there could be several effects which include: the loss of that employee's competence and skills, knowledge and abilities; secondly, the organization may experience poor service delivery; thirdly, the financial impact of replacing such employee cannot be overemphasized. To achieve a match between job and job holders in the Nigerian public sector organizations, this study recommends that, as a matter of necessity, personnel job audit should be conducted quarterly to check the growing incidence of employee idleness and corridor congregation among public servants.

2. Also, for improved service delivery, the Nigerian public sector agencies should through job analysis, identify and develop proper employee commitment scheme such , training and retraining, and performance review standards that could enhance service delivery. These will motivate and keep employees' abreast with current developments in their fields of endeavor. The heads of ministries and extra-ministerial departments should examine and redesign personnel requirements to match position classifications. FAANs public personnel managers in particular and public sector agencies in general are advised to imbibe the prescripts of New Public Management (NPM) that goals and targets should be defined and measurable as indicators of service delivery.

\section{Contribution to Knowledge}

The research opens a new horizon in the field of Human Resource Management (HRM) particularly in a developing country like Nigeria by opening a discussion on the effect of job analysis on public service delivery. The study investigated and statistically established a significant relationship between job analysis and public service delivery. This study has added to the efforts of researchers' world over to understand the association between job analysis and public service delivery. 


\section{Suggestions for Further Studies}

It is instructive to note that though researchers in the western countries have carried out researches in these areas, however, it was observed in the course of our literature review that little or no research has been carried out in these areas in a non-western country like Nigeria. The present study may serve as a drive and template for human resource professionals, upcoming researchers and scholars alike to undertake further research to validate or invalidate the claims of the western scholars as regards the effect of job analysis on employee job satisfaction.

\section{References}

Ajayi, Q. N. (2012). The Effect of record management on public service delivery: a study of Federal Airports Authority of Nigeria (FAAN), an unpublished MPA thesis, department of public administration, Lagos State University, Ojo.

Akhakpe, I. P. (2014). Bureaucracy and good governance. Lagos: Pumark Publishers.

Al-Ahmadi, H. (2009). Factors affecting performance of hospital nurses in Riyadh region, Saudi Arabia, International Journal of Health Care Quality Assurance, 22(1), 40-54. https://doi.org/10.1108/09526860910927943

Alegbeleye, I. G. (2014). The impact of monetization on employees performance: a study of Federal Airports Authority of Nigeria (FAAN), an unpublished M.Sc thesis, department of public administration, Lagos State University, Ojo.

Apospori, E., Nikandrou, I., Brewster, C., \& Papalexandris, N. (2008). HRM and organizational performance in Northern and Southern Europe, International Journal of Human Resource Studies, 19(7), 1187-1207. https://doi.org/10.1080/09585190802109788

Armstrong, M. (2010). A handbook of human resource management practice, London: KoganPage Ltd.

Asika, N. (2006). Research methodology in the behavioural sciences, Lagos: Longman Nigeria.

Babbie, E., \& Mouton, J. (2001). The practice of social research, Cape Town: Oxford University Press.

Bohlander, G., Snell, S., \& Sherman, A. (2009). Managing human resources, New York: South-Western College.

Bowra, Z. A., Sharif, B., \& Niazi, M. K. (2011). Impact of human resource practice on employees' perceived performance in banking sector of Pakistan, African Journal of Economic and Management Studies, 1(2), 128-137.

Briggs, R. B. (2007). Problems of recruitment in civil service: case of the Nigerian civil service, African Journal of Business Management, 1(6), 142-153.

Cascio, W. (2010). Managing human resources. New York: McGraw-hill.

Cavanaugh, C. M. (2011). The effects of job characteristics on citizenship performance, an unpublished M.Sc thesis submitted to the postgraduate school Purdue University, Indianapolis, Indiana. 
Chukwuemeka, E. E. O. (2013). The substance of public administration in Nigeria (a compendium of public policy and local government), Enugu: Professor's Press.

Clifford, J. (1994). Job analysis: why do it and how should it be done? Public Personnel Management, 23, 321-40. https://doi.org/10.1177/009102609402300211

Dessler, G., Cole, N. D., \& Sutherland, V. L. (2012). Human resource management in Canada, Scarborough, ON: Prentice Hall Canada.

Dibie, R. A. (2014). Public administration: theory, analysis and application. Ilishan-Remo, Ogun: Babcock University Press.

Dibie, R., Edoho, F., \& Dibie, J. (2015). Analysis of capacity building and economic growth in sub-saharan Africa, International Journal of Business and Social Science, 6(12), 1-25.

Dunsire, A. (1995). Administrative theory in the 1980s: A viewpoint. Public Administration, 73, 17-40. https://doi.org/10.1111/j.1467-9299.1995.tb00815.x

Fagbemi, A. (2006). Customer service delivery in public sector management, Lagos: Concepts Publication Limited.

Federal Republic of Nigeria (FRN). (1999). 1999 Constitution as amended, Abuja: Government Printer

Gomez-Mejia, L. R., Balkin, D. B., \& Cardy, R. L. (2010). Managing human resources. Upper Saddle River, New Jersey: Prentice Hall.

Griffin, R., Phillips, J. M., \& Gully, S. M. (2017). Organizational behavior: managing people and organizations. $12^{\text {th }}$ Editions. Boston, M.A.: Cengage Learning.

Guest, D., Michie, J., Conway, N., \& Sheehan, M. (2003). Human resource management and corporate performance in the UK, British Journal of Industrial Relations, 41(2), 291-314. https://doi.org/10.1111/1467-8543.00273

Harvey, R. J. (1991). Job analysis, in Dunnette, M.D, Hough. L.M, (eds.), Handbook of industrial and organizational Psychology, Palo Alto: Consulting psychologists Press, 12, 71-164.

Hitt, A. M., Ireland, R. D., \& Hoskisson, R. E. (2017). Strategic management: concepts and cases: competitiveness and globalization. 12th Edition. Boston, M.A.: Cengage Learning.

Hood, C. (1991). A public management for all seasons' Public Administration (69) Spring. https://doi.org/10.1111/j.1467-9299.1991.tb00779.x

Igbokwe-Ibeto, C. J., \& Aremo, M. O. (2013). Reward and reward management: an antidote for productivity enhancement in the Nigerian public sector organizations, Journal of Policy and Development Studies, 8(2), 1-12.

Igbokwe-Ibeto, C. J., Akhakpe, I., \& Agboola, T. O. (2013). The impact of human resource management practices on organisational performance: a study of Lagos state university, (LASU) Ojo, Ife Journal of the Humanities and Social Studies, 1(2), 41-58.

Igbokwe-Ibeto, C. J., Osakede, K. O., \& Anazodo, R. O. (2015), The Effect of Manpower Planning and Development in Lagos State Civil Service Performance, Africa's Public Service Delivery and Performance Review, 3(4), 76-116. https://doi.org/10.4102/apsdpr.v3i4.99 
ISSI (2015). Four key elements of a service delivery system, retrieved from http://service/features.com/faculty-management

Klingner, D., Nalbandian, J., \& Llorens, J. (2010). Public personnel management, Upper Saddle River, New Jersey: Pearson/Prentice Hall.

Lueder, K. (1996). Triumph des marktesimoeffentlichensektor? — einigeAnmerkungenzuraktuellenverwaltungsreformdiskussi on, Die oeffentlicheVerwaltung, 49, 93-100.

Lussier, R. (2012). Management fundamentals: concepts, applications and skills development. Mason, OH: South Western/ Cengage Press.

Lussier, R., \&Achua, C. (2017). Leadership: theory, application and skill development. Sixth Edition, Boston, M.A.: Cengage Learning.

Mapira, N., Katsuro, P., Chazuza, T., Mlingwa, M. M., Togarepi, M., Mutambatuwisi, F., Nhimba, N. K., Umera, T., \& Machigere, T. (2013). The importance of establishing job analysis exercise in an organisation: a case study of bread manufacturing companies in Zimbabwe ,Australian Journal of Business and Management Research, 2(11), 35-42.

Mouton, J., \& Marais, H. C. (1990). Basic concepts in the methodology of the social sciences, Pretoria: HSRC.

Mukoro, A. (2005). Ecology of recruitment and selection of personnel in the Nigerian federal civil service, Journal of Human Ecology, 17(1), 31-37. https://doi.org/10.1080/09709274.2005.11905754

National Population Commission. (NPC) (2013). Nigeria's population estimate, Abuja: Government Printer.

Newman, C. E. (2011). Effects of job analysis and personnel utilization in Nigerian Ports Authority (NPA) Electronic copy available at: http://ssrn.com/abstract=2178902 10/5/2015.

O’Toole, Jr. L. J., \& Meier, K. J. (2011). Public management: organizations, governance and performance, London: Cambridge University Press.

Obisi, C. (2003). Personnel management, Lagos: Freeman.

Olowu, N. (2011). Contemporary labour economics, New York: McGrew-Hill.

Onyekwelu, R. U. (2016). Minimum wage implementation and service delivery in the Nigerian civil service: a comparative study of the south east states (2000-2014). An unpublished $\mathrm{PhD}$ dissertation submitted to the postgraduate school, department of Administration, Nnamdi Azikiwe University, Awka.

Rehman, S., Ajmal, W., \& Khatta, H. R. (2010). Impact of job analysis on job performance: analysis of a hypothesized model, Journal of Diversity Management, 5(2), 17-36.

Reichard, \& H. Wollmann, Kommunalverwaltungimmodernisierungsschub, Basel: Birkhaeuser.

Reichard, C. (1996). Die 'New Public Management': debatteiminternationalenkontext. In: C.

Schuler, R. S., \&Jackson, S. E. (1998). Human resource management: positioning for the 21st century, St Paul: West Publishing. 


\section{Macrothink}

International Journal of Human Resource Studies

ISSN 2162-3058 2019, Vol. 9, No. 2

Ukaegbu, C. C. (1995). Work content in the Nigerian civil service, Nigerian Journal of Public Administration and Local Government, 6(1), 44-55.

United States Office of Personnel Management, 2008, Hiring toolkit. Retrieved July 22, 2015, from Job analysis tool Web site: http://www.opm.gov/hiringtoolkit/ docs/jobanalysis.pdf.

Yamani, T. (1967). Statistics: an introductory analysis. New Delhi: Yani Publisher.

\section{Copyright Disclaimer}

Copyright for this article is retained by the author(s), with first publication rights granted to the journal.

This is an open-access article distributed under the terms and conditions of the Creative Commons Attribution license (http://creativecommons.org/licenses/by/4.0/). 